\title{
The Effects of Manual and Powered Brushing with a Tooth Brush on Surface Roughness Alteration of Different Resin and Glass Ionomer-based Restorative Materials: An In Vitro Study
}

\author{
Manuel ve Elektrikli Diş Fırçalamanın Rezin ve Cam lyonomer \\ Esaslı Farklı Restoratif Materyallerin Yüzey Pürüzlülügünün \\ Değişimi Üzerine Olan Etkileri: Bir In Vitro Çalışma
}

(D) Akif Demirel ${ }^{1}$, (D) Nilsun Bağış ${ }^{2}$

${ }^{1}$ Ankara University Faculty of Dentistry, Department of Pediatric Dentistry, Ankara, Turkey

${ }^{2}$ Ankara University Faculty of Dentistry, Department of Periodontology, Ankara, Turkey

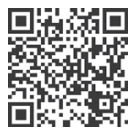

Keywords

Toothbrushing, restorative materials, surface roughness

Anahtar Kelimeler

Diş fırçalama, restoratif materyaller, yüzey pürüzlülüğü

Received/Geliş Tarihi : 13.03.2021

Accepted/Kabul Tarihi : 01.04.2021

doi:10.4274/meandros.galenos.2021.38233

Address for Correspondence/Yazışma Adresi: Akif Demirel DDS,

Ankara University Faculty of Dentistry,

Department of Pediatric Dentistry, Ankara,

Turkey

Phone : +90 3122965662

E-mail : akifdemirel@ankara.edu.tr

ORCID ID: orcid.org/0000-0002-1433-0452

(C) Meandros Medical and Dental Journal, Published by Galenos Publishing House.

This is article distributed under the terms of the

Creative Commons Attribution NonCommercial 4.0

International Licence (CC BY-NC 4.0).

\section{Abstract}

Objective: This study aimed to present a comparative evaluation of the effects of manual and powered brushing with a tooth brush on surface roughness of different resin and glass ionomer-based restorative materials.

Materials and Methods: A total of 160 discs were prepared from four different restorative materials (resin, compomer, high-viscosity glass ionomer and conventional glass ionomer-based materials). Half of the specimens from each group were brushed manually, and the other half were power-brushed. The surface roughness $(\mathrm{R} a)$ values before and after brushing $(\triangle \mathrm{Ra})$ were measured, recorded and statistically analysed. Student's t-test, Mann-Whitney U and Kruskal-Wallis $\mathrm{H}$ tests were used for statistical comparisons. The statistical significance level was determined as $5 \%$.

Results: An increase in the surface roughness was observed in all restorative materials after manual and powered brushing. However, no statistically significant difference was observed among the different restorative materials in terms of the increase in roughness ( $p>0.05$ ). Additionally, no statistically significant difference was found between manual and electric brushing in terms of the increase in surface roughness of the restorative materials ( $p>0.05$ ).

Conclusion: The restorative materials examined in this study did not have any superiority or disadvantage over each other in terms of the increase in surface roughness after manual and powered brushing. In addition, as powered brushing does not lead to extra roughness compared with manual brushing and owing to its other advantages, the use of powered toothbrushes can be recommended for improving oral hygiene in children.

Öz

Amaç: Bu çalışma, manuel ve elektrikli diş fırçalamanın farklı rezin esaslı ve cam iyonomer esaslı restoratif materyallerin yüzey pürüzlülüğüne olan etkilerinin karşılaştırmalı olarak değerlendirilmesini sunmayı amaçlamıştır. 
Gereç ve Yöntemler: Dört farklı restoratif materyale ait (rezin, kompomer, yüksek vizkoziteli cam iyonomer ve geleneksel cam iyonomer esaslı materyaller) 160 adet restoratif materyal diskleri hazırlanmışıı. Her gruba ait örneklerin yarısı manuel, diğer yarısı da elektrikli fırça ile fırçalanmıştır. Fırçalama öncesi ve sonrası yüzey pürüzlülük değerleri (Ra) ölçülmüş, kaydedilmiş ve pürüzlülük değişim $(\Delta R a)$ değerleri istatistiksel olarak analiz edilmiştir. İstatistiksel karşılaştırmalarda, Student $t$-test, Mann-Whitney $U$ ve Kruskal-Wallis $\mathrm{H}$ testleri kullanıımıştır. İstatistiksel anlamlııı düzeyi \%5 olarak alınmıştır.

Bulgular: Hem manuel hem de elektrikli fırçalamadan sonra, tüm restoratif materyallerde, yüzey pürüzlülüğünde artış bulunmuş ancak restoratif materyaller arasında pürüzlülük artışı açııından istatistiksel olarak anlamlı bir farklılık tespit edilmemiştir $(p>0,05)$. Ayrıca, restoratif materyallerin yüzey pürüzlülüğü artışı açısından, manuel ve elektrikli fırçalama arasında istatistiksel olarak anlamlı bir farklıık tespit edilmemiştir $(p>0,05)$.

Sonuç: Hem manuel hem de elektrikli fırçalama sonrası, yüzey pürüzlülüğü artışı açısından restoratif materyallerin birbirlerine üstünlügünün ya da dezavantajının olmadığı sonucuna varılmıştır. Ayrıca, elektrikli fıçcalamanın manuel fırçalamaya oranla ekstra pürüzlülük yaratmamış olması ve sunduğu diğer avantajlar göz önüne alınarak, çocuklarda oral hijyenin sağlanmasında elektrikli fırçaların kullanımı önerilebilir.

\section{Introduction}

Despite all the advances in dental caries prevention, caries formation is still a major clinical problem which increases the need for the restoration of dental structures and restorative materials (14). Many different materials are used in restorative treatments in pediatric dentistry such as composites, polyacid-modified composite resins (compomers) and glass ionomer-based materials. The resin-containing materials are preferred due to its high adhesive and aesthetic properties, while glass ionomer-based materials are preferred due to their easy-to-handle properties, anti-caries features, fluoride release/ fluoride charging abilities $(1,2,5)$. On the other hand, high viscosity glass ionomers produced for atraumatic restorative treatment (ART) approach, which is especially carried out in outreach situations, are among the materials offered to the clinician as a subgroup of glass ionomer materials $(6,7)$. Nowadays, with coronavirus disease-2019 (COVID-19) pandemic, minimal intervention dentistry (MID) approach, and ART-which is a part of the MID approach- are adopted for reducing the amount of aerosol formation and the chair time. Considering both these aspects and other advantages, the use of glass ionomer-containing materials is as much used as resin-containing materials in pediatric dentistry clinics $(2,7,8)$.

The most effective method to prevent dental caries and periodontal diseases is toothbrushing with an appropriate dentifrice. The aim of using dentifrice is to enhance chemical plaque removal effectiveness in addition to mechanical cleaning $(4,9,10)$. On the other hand, abrasive substances consisting of insoluble inorganic compounds are added to dentifrices in order to effectively clean the dental surfaces and remove stains $(9,11)$. However, since dentifrices contain abrasives, it is known that toothbrushing causes an increase in the surface roughness of dental restorative materials (11-13). Although it is recommended that the amount of abrasive material is less in dentifrices for children, it is an inevitable fact that abrasives increase the surface roughness $(13,14)$. On the other hand, the increase in surface roughness after toothbrushing increases the dental plaque accumulation, staining due to pigmentations and the risk of dental caries formation $(13,15,16)$.

Powered toothbrushing is as common as manual toothbrushing in children's daily oral care. The use of powered toothbrushes tends to increase especially due to deep cleaning abilities at the gingival margins and in hard-to-reach interdental areas (17-19). On the other hand, the use of powered toothbrushing in children assist to overcome the problems of lack of motivation and poor brushing technique (20). It has also been shown that the use of powered toothbrushing in both primary and permanent teeth is more effective than manual toothbrushing in children (21) and therefore powered brushing is recommended to increase oral health status in children (19).

In the literature, only a limited number of studies have examined the effects of both manual and powered toothbrushing on the surface roughness of restoratives. Therefore, this study aimed at presenting a comparative evaluation of the effects of manual and powered toothbrushing on surface roughness alteration in different resin and glass ionomer-based restorative materials under in vitro conditions. The null hypothesis tested in the present study was that there would not be statistically difference between 
both different restorative materials and brushing procedures regarding surface roughness alteration.

\section{Materials and Methods}

\section{Study Design and Preparation of the Specimens}

This study has followed the CRIS guidelines for in vitro research as discussed in 2014 concept note (22). A total of 160 restorative disc-shaped specimens of 4 different types of restorative materials were prepared according to manufacturer's recommendations $(n=40)$. Restorative materials included in this study were nano-hybrid composite (Clearfil Majesty Posterior), polyacid-modified composite resin (Dyract XP), high viscosity glass ionomer (Equia Fil), and conventional glass ionomer (Ionofil Molar) (Table 1). Teflon-based ring molds were used to prepare restorative discshaped specimens (diameter: $10 \mathrm{~mm} \times$ height: $2 \mathrm{~mm}$ ). Disc-shaped restorative specimens were polished via polishing discs (Sof-Lex, 3M ESPE, St. Paul, MN, USA) by a handpiece at 15,000 rpm for 10 seconds. Then, the specimens were hydrated in distilled water at 37 ${ }^{\circ} \mathrm{C}$ for 24 hours.

Forty samples in each restorative material group were assigned to the 2 subgroups $(n=20)$ of manual (Oral-B Stages 3 Manual Toothbrush, aged 5-7, Oral B, USA) and powered (Oral B Junior Powered Toothbrush, aged $6+$, Oral B, USA) toothbrushes.

\section{Brushing Procedures}

For both manual and powered brushing, discshaped restorative material samples were brushed with $2 \mathrm{~mL}$ of same dentifrice (Oral-B Stages Kids Dentifrice, aged 5-7, Oral B, USA) for 2 minutes every day to simulate home brushing procedures. All the specimens were brushed every day at 12-hour intervals for 90 days. The specimens were washed under tap water after brushing and immersed in distilled water at $37{ }^{\circ} \mathrm{C}$ until the next brushing. After the brushing process was completed, surface roughness was measured. Specimens were brushed by the same operator (A.D.) at the same motion force of brushing.

\section{Surface Roughness Measurements}

Surface roughness measurements were performed via a profilometer (Perthometer M2, Mahr, Germany). For the surface roughness measurement, the Ra value read on the profilometer device was used. Three consecutive measurements were performed on the surface of all the samples and the mean values were recorded. Surface roughness $(\mathrm{Ra})(\mu \mathrm{m})$ of the specimens were measured before (baseline: $R a_{B}$ ) and after (final: $R a_{F}$ ) both brushing procedures. After 90 days of the brushing procedure, surface roughness alteration ( $\triangle R a$ ) was measured based on the differences between $\mathrm{Ra}_{\mathrm{F}}$ and $\mathrm{Ra}_{\mathrm{B}}$ values. Subsequently, surface roughness alteration $(\Delta R a)$ values for each restorative material and brushing method were analyzed statistically. The equation for surface roughness alteration measurement is given below:

$$
\Delta \mathrm{Ra}=\mathrm{Ra}_{\mathrm{F}}-\mathrm{Ra}_{\mathrm{B}}
$$

\section{Statistical Analysis}

SPSS 11.5 software was used to analyze the study findings. As descriptive, mean \pm standard deviation (SD) and median (minimum-maximum) were used for quantitative variables, and (\%) for qualitative variables. In terms of the quantitative variable, whether there is a difference between categories of qualitative variable with two categories was analyzed using Student's t-test if normal distribution assumptions were provided, and Mann-Whitney $\mathrm{U}$ test if not. In terms of the quantitative variable, whether there is a difference between categories of qualitative variable with more than two categories was analyzed using the Kruskal-Wallis $\mathrm{H}$ test, since normal distribution assumptions were not provided. Statistical significance level was taken as $5 \%$.

\section{Results}

After manual toothbrushing, no statistically significant difference was found between the restorative materials in terms of surface roughness alteration $(\triangle R a)(p=0.279)$. The mean $\pm S D$ values of the surface roughness alteration $(\mu \mathrm{m})$ of all the restorative materials were $0.11 \pm 0.04,0.12 \pm 0.04$, $0.10 \pm 0.06$ and $0.10 \pm 0.05$, respectively (Table 2 ). Accordingly, after manual toothbrushing, an increase in surface roughness ( $\Delta \mathrm{Ra}>0$ ) occurred in all restorative materials examined in the present study.

After powered toothbrushing, no statistically significant difference was found between the restorative materials in terms of surface roughness alteration $(\Delta R a)(p=0.813)$. The mean $\pm S D$ values of the surface roughness alteration $(\mu \mathrm{m})$ of all the restorative materials were $0.11 \pm 0.08,0.09 \pm 0.05$, $0.10 \pm 0.04$ and $0.09 \pm 0.04$, respectively (Table 2 ). 
Accordingly, after powered toothbrushing, an increase in surface roughness ( $\triangle \mathrm{R} a>0)$ occurred in all restorative materials examined in the present study.

For all restorative material groups, no statistically significant difference was found between manual and powered brushing procedures in terms of surface roughness alteration $(\Delta \mathrm{Ra}) \quad(\mathrm{p}=0.820, \mathrm{p}=0.174$, $p=0.959$ and $p=0.564$, respectively) (Table 3 ).

\section{Discussion}

Despite all the improvements regarding the oral health status of children, dental caries is still an important oral health problem, especially in socioeconomically-deprived populations $(3,4)$. To intercept dental caries and periodontal diseases, removing microbial dental plaque and maintaining the oral hygiene are important $(4,9,23)$. In toothbrushing procedures, dentifrices are used to remove the dental plaque chemically in addition to the mechanical cleaning of the toothbrush $(9,10,24)$. However, due to the mechanical movement/action of the bristles of toothbrushes and the effect of the abrasives in the dentifrices, the surface roughness of the dental hard tissues and the restorative materials increases $(10,13)$. The increased surface roughness accelerates dental plaque accumulation, caries formation and staining caused by pigmentation. In this respect, it is also important to detect the increase in surface roughness of restorative materials after toothbrushing $(13,15,16)$. Based on this view, the present study aimed to assess the effects of different

\begin{tabular}{|l|l|l|l|}
\hline \multicolumn{2}{|l|}{ Table 1. Material type and its compositions of restorative materials used in the present study } \\
\hline $\begin{array}{l}\text { Type of restorative } \\
\text { material }\end{array}$ & Commercially brand name & Composition & Manufacturer company \\
\hline Nano-hybrid composite & Clearfil Majesty Posterior & $\begin{array}{l}\text { Bis-GMA, TEGDMA, hydrophobic aromatic } \\
\text { dimethacrylate }\end{array}$ & $\begin{array}{l}\text { Kuraray Medical Co, } \\
\text { Tokyo, Japan }\end{array}$ \\
\hline $\begin{array}{l}\text { Polyacid-modified } \\
\text { composite resin }\end{array}$ & Dyract XP & $\begin{array}{l}\text { UDMA Strontium-fluoro-silicate glass, } \\
\text { strontium fluoride, TCB resin, photoinitiator } \\
\text { and stabilizers }\end{array}$ & $\begin{array}{l}\text { Dentsply, DeTrey, } \\
\text { Konstanz, Germany }\end{array}$ \\
\hline $\begin{array}{l}\text { High viscosity glass } \\
\text { ionomer }\end{array}$ & Equia Fil & $\begin{array}{l}\text { Strontium fluoroalumino-silicate glass, } \\
\text { polyacrylic acid, aqueous polyacrylic acid }\end{array}$ & $\begin{array}{l}\text { GC Corporation, Tokyo, } \\
\text { Japan }\end{array}$ \\
\hline $\begin{array}{l}\text { Conventional glass } \\
\text { ionomer }\end{array}$ & lonofil Molar & $\begin{array}{l}\text { Water, pure polyacrylic acid, tartaric acid, } \\
\text { aluminofluorosilicate glass and pigments }\end{array}$ & $\begin{array}{l}\text { Voco, Cuxhaven, } \\
\text { Germany }\end{array}$ \\
\hline
\end{tabular}

Table 2. The mean \pm SD and median (min-max) values of surface roughness alteration $(\Delta R a)(\mu m)$ for each restorative material group and results of statistical comparisons

\begin{tabular}{|c|c|c|c|c|c|c|c|}
\hline \multicolumn{4}{|c|}{ Manual brushing } & \multicolumn{4}{|c|}{ Powered brushing } \\
\hline $\begin{array}{l}\text { Restorative } \\
\text { materials }\end{array}$ & \multicolumn{2}{|c|}{$\begin{array}{l}\text { Surface roughness alteration }(\Delta R a) \\
(\mu \mathrm{m})\end{array}$} & p-value & $\begin{array}{l}\text { Restorative } \\
\text { materials }\end{array}$ & \multicolumn{2}{|c|}{$\begin{array}{l}\text { Surface roughness alteration ( } \Delta \mathrm{Ra}) \\
(\mu \mathrm{m})\end{array}$} & p-value \\
\hline \multirow{2}{*}{$\begin{array}{l}\text { Clearfil } \\
\text { majesty } \\
\text { posterior }\end{array}$} & Mean \pm SD & $0.11 \pm 0.04$ & \multirow{8}{*}{$0.279^{\mathrm{a}}$} & \multirow{2}{*}{$\begin{array}{l}\text { Clearfil } \\
\text { majesty } \\
\text { posterior }\end{array}$} & Mean \pm SD & $0.11 \pm 0.08$ & \multirow{8}{*}{$0.813^{\mathrm{a}}$} \\
\hline & Median (min-max) & $\begin{array}{l}0.10 \\
(0.05-0.19)\end{array}$ & & & Median (min-max) & $\begin{array}{l}0.10 \\
(0.01-0.28)\end{array}$ & \\
\hline \multirow[b]{2}{*}{ Dyract XP } & Mean \pm SD & $0.12 \pm 0.04$ & & \multirow[b]{2}{*}{ Dyract XP } & Mean \pm SD & $0.09 \pm 0.05$ & \\
\hline & Median (min-max) & $\begin{array}{l}0.12 \\
(0.06-0.24)\end{array}$ & & & Median (min-max) & $\begin{array}{l}0.09 \\
(0.01-0.19)\end{array}$ & \\
\hline \multirow[b]{2}{*}{ Equia Fil } & Mean \pm SD & $0.10 \pm 0.06$ & & \multirow[b]{2}{*}{ Equia Fil } & Mean \pm SD & $0.10 \pm 0.04$ & \\
\hline & Median (min-max) & $\begin{array}{l}0.10 \\
(0.01-0.23)\end{array}$ & & & Median (min-max) & $\begin{array}{l}0.09 \\
(0.03-0.19)\end{array}$ & \\
\hline \multirow[b]{2}{*}{ Ionofil molar } & Mean \pm SD & $0.10 \pm 0.05$ & & \multirow[b]{2}{*}{ Ionofil molar } & Mean \pm SD & $0.09 \pm 0.04$ & \\
\hline & Median (min-max) & $\begin{array}{l}0.10 \\
(0.03-0.22)\end{array}$ & & & Median (min-max) & $\begin{array}{l}0.09 \\
(0.02-0.17)\end{array}$ & \\
\hline
\end{tabular}


Table 3. The statistical comparison between manual and powered brushing in terms of surface roughness alteration $(\Delta R a)$ for each restorative material

\begin{tabular}{|c|c|c|c|c|c|}
\hline \multirow{3}{*}{ Restorative materials } & \multicolumn{2}{|c|}{ Manual brushing } & \multicolumn{2}{|c|}{ Powered brushing } & \multirow{3}{*}{ p-value } \\
\hline & \multicolumn{2}{|c|}{ Surface roughness alteration $(\Delta R a)(\mu m)$} & \multicolumn{2}{|c|}{$\begin{array}{l}\text { Surface roughness alteration ( } \Delta R a) \\
(\mu \mathrm{m})\end{array}$} & \\
\hline & Mean \pm SD & Median (min-max) & Mean \pm SD & Median (min-max) & \\
\hline Clearfil majesty posterior & $0.11 \pm 0.04$ & $\begin{array}{l}0.10 \\
(0.05-0.19)\end{array}$ & $0.11 \pm 0.08$ & $\begin{array}{l}0.10 \\
(0.01-0.28)\end{array}$ & $0.820^{b}$ \\
\hline Dyract XP & $0.12 \pm 0.04$ & $\begin{array}{l}0.12 \\
(0.06-0.24)\end{array}$ & $0.09 \pm 0.05$ & $\begin{array}{l}0.09 \\
(0.01-0.19)\end{array}$ & $0.174^{b}$ \\
\hline Equia Fil & $0.10 \pm 0.06$ & $\begin{array}{l}0.10 \\
(0.01-0.23)\end{array}$ & $0.10 \pm 0.04$ & $\begin{array}{l}0.09 \\
(0.03-0.19)\end{array}$ & $0.959^{a}$ \\
\hline Ionofil molar & $0.10 \pm 0.05$ & $\begin{array}{l}0.10 \\
(0.03-0.22)\end{array}$ & $0.09 \pm 0.04$ & $\begin{array}{l}0.09 \\
(0.02-0.17)\end{array}$ & $0.564^{a}$ \\
\hline
\end{tabular}

toothbrushing procedures on the changes in surface roughness of restorative materials. In this respect, this study investigated the changes/alterations in surface roughness of restorative materials $(\Delta R a)$ that occur with toothbrushing rather than the roughness levels before or after brushing.

Although many materials have been used in restorative treatments in pediatric dentistry, resin-containing composite, compomer and glass ionomer-containing materials are among the most preferred $(1,2,5)$. While resin-based materials such as composites and compomers are among the materials that are frequently used due to their superior adhesive and aesthetic properties, glass ionomer-based restorative materials are preferred due to their chemical adhesion to dental hard tissues, fluoride releasing/fluoride reservoir features and easy-to-handle properties $(1,2,25,26)$. Moreover, high viscosity glass ionomers are preferred due to their high compressive strength and wear resistance in addition to the advantages offered by traditional glass ionomer materials. Also, high viscosity glass ionomers are used in ART approach based on the MID philosophy that reduces aerosol formation especially during the COVID-19 pandemic $(1,2,7,8)$. Consequently, due to frequent use of resin and glass ionomers in routine clinical practice and outreach situations (especially in ART technique), our study included these restorative materials.

Powered toothbrushing is effective in removing microbial dental plaque in adults as well as children
$(18,20,27,28)$. On the other hand, manual brushing requires more pressure than powered brushing. In addition, powered brushing may be more effective in improving the oral health of individuals with physical or mental disabilities, since it requires less hand movement and motor coordination skills $(17,19,29,30)$. In a pilot study, Durhan et al. (19) stated that powered toothbrushing showed more reduction in dental plaque than manual brushing procedure. In line with above-mentioned properties of powered toothbrushing, which was recommended for use by the other studies in the literature, we included powered toothbrushing in this study procedure in order to investigate its effect on the surface roughness of restorative materials and to be able to make recommendations in this respect. Both manual and powered toothbrushes selected for use in this study were suitable for children. Bristle properties of manual and powered toothbrushes were approximately similar.

Physical removal of the dental plaque in toothbrushing is achieved by the use of a toothbrush and dentifrice containing abrasive particles $(14,31)$. On the other hand, the cleaning process on tooth surfaces depends on factors such as type, morphology and particle size of the abrasive contents $(14,32)$. Many of the benefits provided by abrasive particles are desired in adult pastes regarding plaque removal. However, in children, the amount of abrasive should be balanced in a way that can provide effective cleaning and plaque removal, but not damage the developing 
tooth surfaces (14). On the other hand, as the abrasive content of dentifrices changes, the alterations occur in surface roughness (13). Therefore, in our study, since we investigated to what extent toothbrushing affects the increase in surface roughness of the restorative materials, dentifrices suitable for children in terms of abrasive properties and other features were used in our study.

According to the findings of the present study, surface roughness increase was detected in all the materials both after manual and powered toothbrushing. However, no significant difference was found between the amounts of rise in surface roughness in all the restorative materials both after manual and powered brushing procedures. Accordingly, it can be stated that both toothbrushing methods cause similar increase in surface roughness in all the restorative materials used in this study. Pala et al. (33) reported that after powered brushing with two different dentifrices, similar roughness values were found in their study without any statistically significant difference in composite (Clearfil Majesty Posterior) and compomer (Dyract XP) materials. Also, similar to our study, Mondelli et al. (34) reported that several different commercially available compomer restorative materials (Dyract, Dyract AP, Compoglass F) showed surface roughness increase without statistically significant difference between dental composites (Z100 and Silux Plus) after simulated toothbrushing. On the other hand, Dudás et al. (13) reported that the increase in surface roughness of glass ionomer-based restorative material was the highest compared to composites, in contrast with the findings of the present study. This difference can be attributed to the different effects of dentifrices on surface roughness of restorative materials, since the dentifrices used in the studies were different. On the other hand, considering the fact that there are not many studies comparing the increase in roughness on the surfaces of different restorative materials after tooth brushing, we attribute the statistically similar increase in surface roughness in our study to the use of pediatric dentifrice with low abrasive content. If this analysis was performed with dentifrices with higher abrasive particle sizes or whitening effect, the results might have been different, and in this respect, further studies are needed to investigate effects of different pastes containing different abrasives.
Consequently, considering that the similar surface roughness increases of high viscosity glass ionomers compared to the other materials examined in this study, it is possible to recommend the use of the high viscosity glass ionomer materials in ART applications, which has gained popularity in clinics due to reducing aerosol amount during the COVID-19 pandemic. Moreover, one of the limitations of this study was the 3-month brushing period. Considering the serving period of restorative materials in oral cavity, further studies that use a brushing simulator are required in order to show the changes in the surface roughness of the restorative materials in longer term.

In the present study, no statistical difference was found between manual and powered brushing procedures in terms of surface roughness alterations in different restorative materials. Although there are not enough studies in the literature that compare manual and powered brushing in this respect in restorative materials, the absence of statistically significant difference was attributed to the similar hardness of the bristles in toothbrushes. Powered brushes have advantages such as effective cleaning of inaccessible areas especially gingival margins and interproximal areas, effective plaque removal properties and providing personalized tracking and feedback features in more advanced models (18). Moreover, pediatric patients lack motivation, compliance and adequate manual dexterity in toothbrushing. In this respect, powered toothbrushes help children overcome their lack of motivation, solve brushing problems, circumventing the need for good manual dexterity $(18,20,35)$. Also, in a randomized clinical study, Davidovich et al. (18) reported that powered toothbrushing provided superior plaque reduction in children than manual toothbrushing. In this respect, considering both the mentioned advantages of powered brushing and the absence of extra surface roughness in all the restorative materials after powered toothbrushing compared to manual brushing in this study, powered toothbrushing systems can be recommended for providing and maintaining oral hygiene in children.

\section{Conclusion}

The null hypothesis that there would not be statistically differences between both different restorative materials and brushing procedures 
regarding surface roughness alteration was accepted. Within the limitations of this study, after both manual and powered brushing, it is possible to concluded that one of the restorative materials has no advantage or disadvantage over the others in terms of surface roughness increase. In addition, since manual and powered brushing procedures showed no significant difference in surface roughness alteration, the use of powered brushes are recommended children, considering the other advantages.

\section{Ethics}

Ethics Committee Approval: Ethics committee approval is not required for this study.

Informed Consent: For this type of study, informed consent is not required.

Peer-review: Externally and internally peerreviewed.

\section{Authorship Contributions}

Concept: A.D., N.B., Design: A.D., N.B., Supervision: A.D., N.B., Fundings: A.D., N.B., Materials: A.D., N.B., Data Collection or Processing: A.D., N.B., Analysis or Interpretation: A.D., N.B., Literature Search: A.D., N.B., Writing: A.D., N.B., Critical Review: A.D., N.B.

Conflict of Interest: No conflict of interest was declared by the authors.

Financial Disclosure: The authors declared that this study received no financial support.

\section{References}

1. Mahoney E, Kilpatrick N, Johnston T. Restorative paediatric dentistry. In: Cameron AC, Widmer RP, editors. Handbook of pediatric dentistry. Mosby: Maryland Heights, 2008: 71-93.

2. Rodrigues JA, Casagrande L, Araújo FB, Lenzi TL, Mariath AAS. Restorative Materials in Pediatric Dentistry. In: Coelho Leal S, Takeshita Eliana, editors. Pediatric Restorative Dentistry. Porto Alegre: Springer, 2019: 161-7.

3. Petersen PE. The World Oral Health Report 2003: continuous improvement of oral health in the 21st century--the approach of the WHO Global Oral Health Programme. Community Dent Oral Epidemiol 2003; 31: 3-23.

4. dos Santos AP, Nadanovsky P, de Oliveira BH. A systematic review and meta-analysis of the effects of fluoride toothpastes on the prevention of dental caries in the primary dentition of preschool children. Community Dent Oral Epidemiol 2013; 41: 1-12.

5. Yildirim S, Uslu YS. Effects of different pediatric drugs and toothbrushing on color change of restorative materials used in pediatric dentistry. Niger J Clin Pract 2020; 23: 610-8.

6. Olegário IC, Malagrana APVFP, Kim SSH, Hesse D, Tedesco TK, Calvo AFB, et al. Mechanical Properties of High-Viscosity Glass
Ionomer Cement and Nanoparticle Glass Carbomer. J Nanomat 2015; 2015: 1-4.

7. Frencken JE. The art and science of Minimal Intervention Dentistry and Atraumatic Restorative Treatment. 1st ed. Comberton: Orleton; 2018.

8. BaniHani A, Gardener C, Raggio DP, Santamaría RM, Albadri S. Could COVID-19 change the way we manage caries in primary teeth? Current implications on Paediatric Dentistry. Int J Paediatr Dent 2020; 30: 523-5.

9. Bulut M, Yıldırım S, Ulukapı I. Diş Macunları ve Fluor. In: Menteş A, editör. Diş Hekimliğinde Fluor. 1. Baskı. Ankara: Türkiye Klinikleri, 2020: 42-7.

10. Loitongbam M, Mohan R, Chowdhary Z, Mehrotra S. Comparative evaluation of tooth surface roughness caused by three different powered toothbrushes and a novel manual toothbrush -An SEM and AFM study. Indian J Dent Res 2020; 31: 743-51.

11. Monteiro B, Spohr AM. Surface Roughness of Composite Resins after Simulated Toothbrushing with Different Dentifrices. J Int Oral Health 2015; 7: 1-5.

12. Rios D, Honôrio HM, de Araújo PA, Machado MA. Wear and superficial roughness of glass ionomer cements used as sealants, after simulated toothbrushing. Pesqui Odontol Bras 2002; 16: 343-8.

13. Dudás C, Forgó Z, Kerekes-Máthé B. Surface Roughness Changes of Different Restoration Materials after Tooth Brushing Simulation Using Different Toothpastes. Journal of Interdisciplinary Medicine 2017; 2: 21-4.

14. Stovell AG, Newton BM, Lynch RJ. Important considerations in the development of toothpaste formulations for children. Int Dent J 2013; 63: 57-63.

15. Bollen CM, Lambrechts $P$, Quirynen $M$. Comparison of surface roughness of oral hard materials to the threshold surface roughness for bacterial plaque retention: a review of the literature. Dent Mater 1997; 13: 258-69.

16. Abouelatta OB, Abdel-Samad AA, Sakrana AA. Wear and surface roughness of current veneered materials after toothbrush/ dentifrice abrasion. J Mater Proc Tech 2005; 168: 431-7.

17. Avinash J, Singh A, Singh DK. Powered Toothbrush vs Manual Toothbrush: Generation X of Mechanical Plaque Control. Int J Prev Clin Dent Res 2017; 4: 122-32.

18. Davidovich E, Ccahuana-Vasquez RA, Timm H, Grender J, Cunningham P, Zini A. Randomised clinical study of plaque removal efficacy of a power toothbrush in a paediatric population. Int J Paediatr Dent 2017; 27: 558-67.

19. Durhan MA, Uluakay $M$, Kargül B. The Plaque Removal Effectiveness of Powered and Manual Tooth Brush in Children: A Pilot Study. Cumhuriyet Dent J 2018; 21: 327-34.

20. García-Godoy F, Marcushamer M, Cugini M, Warren PR. The safety and efficacy of a children's power toothbrush and a manual toothbrush in 6-11 year-olds. Am J Dent 2001; 14: 195-9.

21. Grossman E, Proskin H. A comparison of the efficacy and safety of an electric and a manual children's toothbrush. J Am Dent Assoc 1997; 128: 469-74. 
22. Krithikadatta J, Gopikrishna V, Datta M. CRIS Guidelines (Checklist for Reporting In-vitro Studies): A concept note on the need for standardized guidelines for improving quality and transparency in reporting in-vitro studies in experimental dental research. J Conserv Dent 2014; 17: 301-4.

23. Deinzer R, Cordes $\mathrm{O}$, Weber J, Hassebrauck L, Weik U, Krämer $\mathrm{N}$, et al. Toothbrushing behavior in children - an observational study of toothbrushing performance in 12 year olds. BMC Oral Health 2019; 19: 68.

24. Marinho VC, Higgins JP, Sheiham A, Logan S. Fluoride toothpastes for preventing dental caries in children and adolescents. Cochrane Database Syst Rev 2003; (1): CD002278.

25. Ashwin R, Arathi R. Comparative evaluation for microleakage between Fuji-VII glass ionomer cement and light-cured unfilled resin: a combined in vivo in vitro study. J Indian Soc Pedod Prev Dent 2007; 25: 86-7.

26. Peng Y, Stark PC, Rich A Jr, Loo CY. Marginal microleakage of triage sealant under different moisture contamination. Pediatr Dent 2011; 33: 203-6.

27. Penick C. Power toothbrushes: a critical review. Int J Dent Hyg 2004; 2: 40-4.

28. Ng C, Tsoi JKH, Lo ECM, Matinlinna AJP. Safety and Design Aspects of Powered Toothbrush-A Narrative Review. Dent J (Basel) 2020; 8: 15.
29. Yousaf A, Aman N, Manzoor MA, Yasmin R. Comparison of powered and manual toothbrushes in removal of plaque. Pakistan Oral\&Dental Journal 2012; 32: 120-3.

30. García-Carrillo A, Jover A, Plá R, Martorell A, Sota C, GómezMoreno $G$, et al. Manual versus sonic powered toothbrushing in patients with intellectual disability: a cluster-randomized clinical trial. J Clin Periodontol 2016; 43: 684-93.

31. Hunter ML, Addy M, Pickles MJ, Joiner A. The role of toothpastes and toothbrushes in the aetiology of tooth wear. Int Dent J 2002; 52: 399-405.

32. Schemehorn BR, Moore MH, Putt MS. Abrasion, polishing, and stain removal characteristics of various commercial dentifrices in vitro. J Clin Dent 2011; 22: 11-8.

33. Pala K, Tekçe N, Karakuyu H, Özel E. İki farklı diş macununun farklı restoratif materyallerin yüzey pürüzlülüğü üzerine etkisi. Atatürk Üniversitesi Diş Hekimliği Fakültesi Dergisi 2016; 26: 399-406.

34. Mondelli RF, Wang L, Garcia FC, Prakki A, Mondelli J, Franco $E B$, et al. Evaluation of weight loss and surface roughness of compomers after simulated toothbrushing abrasion test. J Appl Oral Sci 2005; 13: 131-5.

35. Ashkenazi M, Bidoosi M, Levin L. Factors associated with reduced compliance of children to dental preventive measures. Odontology 2012; 100: 241-8. 